UDC 614,2., 614.3, 614.7., 614,9., 574.9.,551.582.,551.583.

DOI: $10.21668 /$ health.risk/2021.1.12.eng

Research article

\title{
CREATING ZONES IN ADMINISTRATIVE DISTRICTS LOCATED IN THE RUSSIAN ARCTIC REGION SPECIFIC AS PER THREATS OF CATTLE BURIALS DECAY DUE TO PERMAFROST DEGRADATION
}

\author{
B.A. Revich ${ }^{1}$, D.A. Shaposhnikov ${ }^{1}$, S.R. Raichich ${ }^{2}$, S.A. Saburova ${ }^{2}$, E.G. Simonova ${ }^{3}$ \\ ${ }^{1}$ Institute of Economic Forecasting of the Russian Academy of Sciences, 47 Nakhimovskii Ave., Moscow, 117418, \\ Russian Federation \\ ${ }^{2}$ Central Research Institute of Epidemiology, 3A Novogireevskaya Str., Moscow, 111123, Russian Federation \\ ${ }^{3}$ I.M. Sechenov First Moscow State Medical University, 2/6 Bol'shaya Pirogovskaya Str., Moscow, 119435, \\ Russian Federation
}

Climatic changes have already resulted and will continue to result in gradual degradation of active upper layers in permafrost due to increased average air temperature in summer. Anthrax is an example of a climate-depending bacterial infection; anthrax agent creates spores that remain viable for a long period of time they spend in cryptobiosis in permafrost. Apparent permafrost degradation is already detected in most arctic regions in Russia and it can lead to anthrax burials decay thus creating elevated risks of the infection among farm animals and people who live on these territories.

Our research goal was to create specific zones in municipal districts via combining data on permafrost, number of anthrax cattle burials, ascending trends in average long-term temperatures, and population density.

We developed two relative hazard coefficients for characterizing anthrax outbreaks probability for animals and local population. Basing on numeric values obtained for these two coefficients, 70 administrative districts located in 15 RF subjects in the Arctic zone were listed in a descending order as per risks of the infection occurrence. We created two score scales showing relative hazard; they indicated that the highest population risk was typical for urban districts as population density there was much high than in rural ones. Our calculations should be helpful for determining priorities when preventive activities are developed on arctic and sub-arctic territories that are endemic as per anthrax. It is also important to obtain an actual list of cattle burials and to develop spatial-time models showing anthrax outbreaks occurrence taking into account climatic warming and permafrost degradation.

Key words: Arctic, Yakutia, climate warming, permafrost, health risks, cattle burials, anthrax.

The founder of Soviet geocryology Mikhail Sumgin introduced the term «permafrost» in geology literature in 1927. Modern geologists also use the term "cryolithozone» as a synonym, to refer to the uppermost layer in the earth's crust, which is characterized throughout the entire year or for at least a short time by a freezing temperature in soils and rocks.
Depending on the frequency with which soil and rock temperatures pass through $0{ }^{\circ} \mathrm{C}$ in the course of the year, the cryolithozone is divided into the layer of short-term and seasonal freezing and thawing, or the «active layer», and the perennial cryolithozone.

The climate in the Arctic currently changes faster than elsewhere on the globe. The rate of

(C) Revich B.A., Shaposhnikov D.A., Raichich S.R., Saburova S.A., Simonova E.G., 2021

Boris A. Revich - Doctor of Medical Sciences, Professor, Head of Laboratory for Environment Quality Prediction and Population Health (e-mail: brevich@yandex.ru; tel.: +7 (499) 129-18-00; ORCID: https://orcid.org/0000-0002-7528-6643).

Dmitry A. Shaposhnikov - Candidate of Physical and Mathematical Sciences, Senior researcher at the Laboratory for Environment Quality Prediction and Population Health (e-mail: dshap2014@gmail.com; tel.: +7 (499) 129-36-33; ORCID: https://orcid.org/0000- 0001-9191-1974).

Stefan R. Raichich - Junior researcher at the Laboratory for Epidemiology of Natural Foci Infections (e-mail: anthraxcrie@gmail.com; tel.: +7 (495) 672-11-73; ORCID: https://orcid.org/0000-0002-7734-7382).

Svetlana A. Saburova - Candidate of Medical Sciences, researcher at the Laboratory for Epidemiology of Natural Foci Infections (e-mail: anthraxcrie@gmail.com; tel.: +7 (495) 672-11-73; ORCID: https://orcid.org/0000-0002-9332-0526).

Elena G. Simonova - Doctor of Medical Sciences, Professor at the Department for Epidemiology and Contemporary Vaccine Prevention Technologies (e-mail: simonova_e_g@mail.ru; tel.: +7 (495) 602-12-75; ORCID: https://orcid.org/00000001-7179-9890). 
increase in the mean annual temperatures over the last four decades (1976-2018) in the Arctic (approximated linearly) is approximately four times higher than the global average [1]. Relatively slow warming could not change the condition of permafrost significantly, but cryolithozone degrades more rapidly under greater warming rates [2]. The rise in the air temperatures gradually warms up the upper permafrost layer. IPCC experts projected a $90 \%$ decrease in the total area of perennial permafrost by 2100 , with an accelerated degradation occurring on a territory equal to $20 \%$ of cryolithozone [3, 4]. The future scenarios of permafrost degradation contain large uncertainties, as they rely on rather generalized assumptions about its properties.

The model-based projections of the trends in air temperatures depend upon the region of interest and GHG emission scenarios. The expected increments in the mean annual temperatures in the selected regions of Russian Arctic over the $21^{\text {st }}$ century were derived from the regionalized climate model under RCP 4.5 emission pathway as follows: $+3.0^{\circ} \mathrm{C}$ in Archangelsk, $+2.0{ }^{\circ} \mathrm{C}$ in Yakutsk. The same increments under RCP8.5 are $+5.0^{\circ} \mathrm{C}$ in Archangelsk and $+3.3{ }^{\circ} \mathrm{C}$ in Yakutsk [5]. The permafrost will gradually melt to remain only in the high mountains and the plains in the northern part of East Siberia and Far East.

Some geocryology scientists believe that permafrost degradation takes place if the upper layer in a cryolite cross-section is exposed to positive mean annual temperatures [6]. This study uses the summer temperatures as an indicator that permafrost degrades. Summer temperatures rise slower than annual mean temperatures in the circumpolar regions. It is during the summer season that permafrost melts down most intensely and the roof of frozen rock sags. The dynamic geocryology models, which link air temperatures to upper permafrost temperatures, are still imprecise, and their predictions vary greatly. According to the following research work, the rise in global mean air temperature by $2{ }^{\circ} \mathrm{C}$ will lead to complete thawing of $15-20 \%$ of today's per- mafrost area [7] whereas another model predicts even greater reductions: by $25-65 \%$ [8].

Perennial permafrost areas in Russian Arctic include the northern European part of Russia (Nenets Autonomous Oblast - NAO), the Urals (Sverdlovsk Oblast), West Siberia (Yamal), the greater part of East Siberia (Krasnoyarsk Krai and Yakutia), Far East (Chukotka Autonomous Oblast, Kamchatka Krai). The rising trends in the temperatures of upper layer in permafrost have been confirmed by numerous field measurements conducted in continuous, sporadic and patchy permafrost areas, and linked to global warming. During the period 1961-2003, temperature increments in permafrost soils at 1.6-meter depth varied between 0.1 and $1.2^{\circ} \mathrm{C}$. The measurements taken at the stationary geocryological stations confirmed that these increments varied considerably even within the same municipal district [9].

Risks of natural focal infections. Permafrost areas degradation is directly linked to the risks of natural focal infections, particularly, to spore-forming bacteria. Prokaryote and eukaryote bacteria can retain viability in permafrost soils where the temperatures stay continuously below zero. Geologic age of these soils varied between several hundred thousand and 2-3 million years. In particular, aerobic and anaerobic bacteria and filamentous fungi have been found and identified in permafrost soils [10-12]. Viable cysts of free-living protozoa have been found in perennial permafrost by many paleobiologic researchers who hypothesised that these spores retained viability in cryptobiosis for several hundred thousand years. These findings confirmed possible reactivation of the pathogens under favourable conditions (thawing and melting of permafrost). This is quite likely to happen in Russian Subarctic during the currently observed climate change [13]. Increasing incidences of haemorrhagic fever with kidney syndrome, tick-borne encephalitis, Lime disease and Karelia fever (transmitted by Sindbis virus) have been reported in some regions of Sweden, Norway, Finland and the Russian Federation by international researchers. Climate change may increase the risks of infections due to several reasons: increases in areas where infectious agents 
survive, warmer winter conditions, and lower depths of snow cover $[14,15]$.

Siberian anthrax as a climate-dependent microbial infection. Epidemic outbreaks of smallpox, cholera, and Siberian anthrax frequently happened in Russian North between the XVII and the first half of the XIX century. The diseased animals were either buried in special burial sites or sometimes just left on the ground. There are over 60 such «field cemeteries» in Yamal peninsula [16]. The problem of anthrax re-emergence due to climate change became obvious when biologists discovered that Bacillus anthracis spores retain viability in permafrost soils for over 100 years. There are more than 520 «officially» catalogued Siberian anthrax cattle burials in Russian Arctic where reindeer and other farm animals were buried. However, another more recent publication mentions 285 such sites, and only 64 out of them meet the established sanitary requirements ${ }^{1}$ [17]. Some experts believe that the most sites fail to meet the sanitary norms due to insufficient communication between epidemiologic surveillance and veterinary authorities, descriptions of such sites being lost, inadequate epizootic maps and other reasons $[18,19]$. Besides, Siberian anthrax burials were insufficiently monitored or even neglected due to numerous reorganizations of the responsible state institutions [20].

The official catalogue of Siberian anthrax burials that we use in this paper lists 230 sites in Yakutia, 84 sites in Archangelsk Oblast, 48 sites in Karelia and 28 sites in Komi Republic ${ }^{1}$.

The statistics of Siberian anthrax outbreaks in Yakutia mentions 739 epizootic outbreaks among reindeer and horses between 1811 and 2019. They happened regularly each decade during this period. The last outbreak was recorded in 1993 [21]. Yakutia (now called Republic Sakha) administratively consists of 35 districts («Ulus»), and epizootic outbreaks were reported in 29 of them. People also caught this infection from cattle and deer [22]. Such profound epizootic-epidemiologic research was performed only in Yakutia, whereas the data on other Arctic regions are less detailed [23].

B. Revich and M. Podolnaya considered potential re-emergence of Siberian anthrax in the context of permafrost degradation near the cattle burial sites in their report [24]. Their hypothesis was confirmed in 2016 when a large scale epizootic outbreak happened in YamalNenets Autonomous Okrug (YANAO). The part of West Siberia located beyond the Polar Circle has long been infamous for Siberian anthrax: more than 70 epizootic outbreaks have been recorded there and there were cases of the disease among people who caught it from animals. A prolonged period of epizootic well-being led people to believe in a false concept Siberian anthrax cattle burials rehabilitated somehow. As a result, vaccination of reindeer was discontinued in 2007. An incredibly warm summer in 2016 in Yamal caused extremely deep seasonal melting of upper layer in permafrost. In some areas, the permafrost thawed at 2-meter depth [25]. During the summer 2016, the mean monthly air temperatures exceeded average long-term ones by $6.7^{\circ} \mathrm{C}$ in June and by $5.7^{\circ} \mathrm{C}$ in July. It is quite likely that these extremely warm summer temperatures contributed to the vegetation of $B$. anthracis colonies in deep frozen strata and their diffusion to the surface with thawed waters, and subsequent large-scale outbreak of epizooty among the reindeer.The local native people contracted this disease through contacts with raw meat. As a result, 24 people became ill, and one 12-years old child died from alimentary contamination [26]. Russian Agricultural Surveillance reported 33 Siberian anthrax outbreaks among reindeer between 2010 and 2016 [27]; single cases of this disease among reindeer were reported in Canada and Scandinavia, but humans have not been infected. This is explained by higher level of education, regular vaccination and updated maps of cattle burials [28].

\footnotetext{
${ }^{1}$ Cadastre of stationary unfavorable Siberian anthrax sites in the Russian Federation. In: B.L. Cherkassky ed. Moscow, Intersen Publ., 2005, 829 p.
} 
There are no published data on spatial statistical relationships between permafrost degradation rates and Siberian anthrax outbreaks in Russian Arctic. The goal of this project was to create a simplified model showing a possible causal relationship between these variables. The authors combined data on permafrost degradation rates, the number of cattle burials, and population density in administrative districts within Russian cryolithozone. For each district, we calculated the hazard index (HI) of future Siberian anthrax outbreaks and linked this index to the observed trends in climate change. All administrative districts were then ranked according to the calculated HI values. The obtained HI values are relative and can be used only to compare the districts between each other according to relative hazard to the local population. The authors did not attempt to calculate actual risks (or probabilities) of future outbreaks as this would require more complex modeling techniques (e.g., models showing ecological niches where Siberian anthrax agent occurred). The statistics on recent outbreaks in administrative districts can be used to confirm the validity of obtained ranking a posteriori.

Materials and methods. The study area. The authors considered the administrative districts with continuous, island-like or patchy permafrost. The numbers of Siberian anthrax cattle burial sites were taken from Cadastre of stationary unfavorable Siberian anthrax sites in the Russian Federation. This Cadastre is maintained by the Federal Service for Surveillance over Consumer Rights protection and Human Well-being (Rospotrebnadzor) and lists the settlements, or other territories, where the Siberian anthrax outbreaks have been registered among cattle or people.

According to the recommendations by Rospotrebnadzor, the whole territory of stationary unfavorable sites (SUS) should be considered as potentially unfavorable and risky in terms of future outbreaks. Seventy administrative districts have been included in this study, located in 15 Russian Federation regions (Table 1). The Cadastre also contains data on the number of «active years» for each site. The authors, at pre- sent, have not used these data due to two reasons: (1) data were unavailable for several regions in the Russian Federation, (2) some sites reported zero years of activity.

Table 1

Regions in the Russian Federation and the number of administrative districts included in the study

\begin{tabular}{|c|c|}
\hline RF region & $\begin{array}{c}\text { Number of } \\
\text { districts }\end{array}$ \\
\hline Murmansk region & 1 \\
\hline Arkhangelsk region & 2 \\
\hline Komi Republic & 11 \\
\hline Komi-Permiatsky Autonomous Okrug ${ }^{*}$ & 4 \\
\hline Nenets Autonomous Okrug & 1 \\
\hline Khanty-Mansi Autonomous Okrug & 4 \\
\hline Yamalo-Nenets Autonomous Okrug & 3 \\
\hline $\begin{array}{l}\text { Taymyr (Dolgano-Nenets) Autonomous } \\
\text { Okrug }\end{array}$ & 3 \\
\hline Krasnoyarsk region & 8 \\
\hline Republic Sakha (Yakutia) $^{* *}$ & 28 \\
\hline Chukotka Autonomous Okrug $^{* * *}$ & 1 \\
\hline Evenk Autonomous Okrug $^{* * *}$ & 1 \\
\hline Koryak Autonomous Okrug & 1 \\
\hline Magadan region $^{* * *}$ & 1 \\
\hline Kamchatka & 1 \\
\hline
\end{tabular}

Notes:

*Including Chusovskoi Urban Okrug in Perm region;

$* *$ The number here represents the greater out of two reported in (Cadaster 2005) and in (Dyagilev et al. 2019);

$* * *$ These regions were considered as single spatial units, and were added to the list of administrative districts located in other regions.

Hazard indices. For each district, two numbers were calculated: «territorial» and «population» hazard indexes. The former $\left(H I_{\text {terr }}\right)$ characterizes the hazard of Siberian anthrax outbreaks within a given territory, the latter $\left(\mathrm{HI}_{\mathrm{pop}}\right)$ measures relative risk of the disease outbreak among the population living in this district.

The territorial index is proportional to two values: (1) the number of the disease agents in cryptobiotic state in permafrost soil which can be measured by the number of stationary unfavorable sites $N$ within this territory and (2) permafrost warming rate. This rate is proportional to the gradient of summer temperatures $\Delta T_{\text {cryo }}$ within the upper layer in permafrost. As this gradient grows, seasonal permafrost thaw- 
ing increases the active layer depth and triggers disease agents activation.

$$
\begin{gathered}
H I_{\text {terr }}=N \cdot \Delta T_{\mathrm{MM \Gamma}} \\
\Delta T_{\text {cryo }}=\Delta T_{\text {air }} \cdot k
\end{gathered}
$$

Where $T_{\text {air }}$ is the change in the mean summer temperatures (June-August) between the two 30-year periods: 1960-1989 and 1990-2019. Temperature measurements were reported by the Federal Weather Service ${ }^{2}$ and taken at the nearest weather station for each district out of the network that included 518 Roshydromet stations. Local stations outside this network have not been considered for the study.

The coefficient $k$ showing how sensitive perennial permafrost is to changes in air temperatures is measured as a ratio between a change in cryolithozone temperature at 10-meter depth and the ground-level air temperature. The seasonal variations in cryolithozone temperature are negligible at this depth («the depth of zero seasonal variations» according to [6]). The recommended normative depth of Siberian anthrax cattle burial or a «biothermal pit» is also 10 meters $^{3}$. Actual depths could vary between 2 meters and 10 meters; the shallowest are plague pits and trenches, the deepest are «furnished burials», according to the available surveys on numerous Siberian anthrax burial sites.

The values of coefficient $k$ that characterizes sensitivity of permafrost to the rise in air temperatures were derived via interpolation from the map publicly presented at a meeting ${ }^{4}$. It varies from 0.3 to 0.8 and can be interpolated and rounded by 0.05 slots within this interval and it imposes a principle limitation on ultimate results precision. Strictly, the calculation of $\Delta T_{\text {cryo }}$ as specified by Eq. (2) at the depth of zero seasonal variations requires using changes in annual mean temperatures. The authors of this study used average summer temperatures for this purpose, because they are directly related to the hazard of reactivation of the agent of Siberian anthrax. For example, the record depth of seasonal thawing of the uppermost layer in permafrost $(2 \mathrm{~m})$ has been observed in Yamal peninsula during the extremely hot summer in 2016. This depth was greater than the long-term seasonal average by $10 \mathrm{~cm} \mathrm{[26].}$

Population hazard index $H I_{\text {pop }}$ was assumed to be the product of $H I_{\text {terr }}$ and the population density:

$$
H Q_{\text {pop }}=H Q_{\text {terr }} \cdot p o p / S \text {, }
$$

where pop and $S$ stand for the population and area of each district. For simplification, Eq. (3) neglects the influence exerted by neighboring districts on Siberian anthrax risks for population. Eq. 3 can be rewritten as

$$
H Q_{\mathrm{pop}}=\left(\Delta T_{\mathrm{MM \Gamma}} \cdot N / S\right) \cdot \text { pop }
$$

where the first term in the brackets is interpreted as the surface density of hazard sources, and the last term is the total exposed population.

Both hazard indices are relative and can only be used for comparison between the districts. Their absolute values do not measure actual risks or probabilities. The result chapter offers an interpretation of the obtained ranking by calculating the relative score associated with the position each district holds on the $H I_{\text {terr }}$ scale.

Eq. (3) implies that one may expect abnormally high $\mathrm{HI}_{\text {pop }}$ values for compact urban administrative districts since their squares are too small in comparison with squares typical for rural areas, for example, when urban districts are actually compact urban settlements (Naryan-Mar, Syktyvkar, and Lesosibirsk).

\footnotetext{
${ }^{2}$ Federal Service of Hydrometeorology and Environmental Monitoring posts these on the website of All-Russian Institute of Hydrometeorology Information. Available at: www.meteo.ru (12.09.2020).

${ }^{3}$ Sanitary and Veterinary Rules of Russian Agricultural Surveillance: Collection, utilization and removal of biological waste, Doc. № 13-7-2/469 of 04.12.1995. Rossel'khoznadzor. Available at: https://fsvps.gov.ru/fsvps/laws/165.html (12.09.2020).

${ }^{4}$ Osipov V.I., Sergeev D.O. Influence exerted by permafrost melting on the functioning of infrastructure in the Far North: a presentation at the meeting of scientific advisory panel of Russian State Committee on Natural Resources Rosprirodnadzor № 2 on 25.06.2020.
} 
Some urban municipalities administratively include rural outskirts which makes their total areas bigger. The authors used the maps showing administrative division of Russia and noticed that often an administrative district does not include its «capital». The examples are the towns of Kudymkar, Khanty-Mansiisk, and Minusinsk. Just like the city of Norilsk is not administratively the part of Taymyr Autonomous Area. In all such cases, the authors used the data on the current administrative division in the Russian Federation and obviously it influenced the ranking order of the districts by $H I_{\text {pop }}$ values.

Results and discussion. Identifying the nearest weather station for each district required extensive work with local administrative maps. About a half (36 out of 70 ) of the districts included in the study had their «own» weather stations - i.e., located on their territories. The longest distance between the nearest weather station and the border of a municipal district was Abansky district of Krasnoyarsk Krai (200 km); Gainsky and Kosinsky districts in Komi-Permiatsky Autonomous Oblast (160 and $170 \mathrm{~km})$.

The highest rise in summer temperatures between the periods 1960-1989 and 1990-2019 was registered in Salekhard $\left(+1.48^{\circ} \mathrm{C}\right)$ and the lowest in Murmansk $\left(+0.43{ }^{\circ} \mathrm{C}\right)$. All weather stations reported positive changes in summer temperatures over the examined period. Calculations of $\Delta T_{\text {cryo }}$ with Eq. (2) showed the greatest increment in Priuralsk district of Yamal-Nenets Autonomous Oblast $\left(+1.0^{\circ} \mathrm{C}\right)$ and the lowest in Kola district of Murmansk Oblast $\left(+0.2^{\circ} \mathrm{C}\right)$.

The available statistics on the numbers of stationary unfavorable sites showed that the greatest numbers were detected in Srednekolymsky and Mirninsky districts of Yakutia (30 and 29 sites).

Table 2 reports the ranking of the administrative districts by territorial and population hazard indices.

A relative score (1 to 6 ) for the territorial hazard index was also assigned basing on its actual calculated values in order to achieve more compact results presentation for better informing provided for all concerned parties. Having analyzed distribution of the estimated $H I_{\text {terr }}$ values we detected its maximum value in Srednekolymskiy district (21.26). The remaining values varied within the interval from 0.17 to 13.24 . These two values differ by less than two orders of magnitude. The scores were assigned linearly after dividing this interval into six equal bins numbered 1 to 6 . Since the width of each bin was equal to $(13.24-0.17) / 6=2.18$, then score $=I$ was assigned to all $H I_{\text {terr }}$ values within the interval $[0.17+(i-1) \cdot 2.18$; $0.17+i \cdot 2.18]$. This scale is a linear one, that is, districts that have scored 2 are approximately two times more hazardous than districts that have scored 1; districts that have scored 3 are about three times more hazardous, etc. Such a scale makes it easier to perceive the research results; still, this perception about relative hazards is valid only within the simples "thawing model" accepted in this work for the anthrax agent. We cannot yet calculate actual risks related to this agent activation. To determine the most relatively hazardous districts, we took those with their scores being 2 or higher; there were 28 such districts or $40 \%$ out of all the considered ones.

The scores of population hazard was calculated on a logarithmic scale, because the underlying distribution of $\mathrm{HI}_{\text {pop }}$ values had (nearly) exponential character. The values of population hazard index differ by five orders of magnitude, between 0.02 in Khatangsky district and 6,747.26 in Naryan-Mar urban okrug. For these reasons, the scores were calculated on a logarithmic scale according to Eq. (4):

$$
S=1+\lg \left(H I / H I_{\text {min }}\right)
$$

where $S$ is hazard given in scores. It follows from Eq. (4) that score $=1$ is assigned to $H I_{\text {terr }}$ values between 0.02 and 0.2 ; score $=2$ to the values between 0.2 and 2.0 , etc. The districts with score $=2$ are approximately ten times more hazardous than the districts with score $=1$; the districts with score $=3$ are approximately 100 times more hazardous than the districts with score $=1$, etc. The logarithmic scales of relative hazards have been previously used in science and engineering, as it meets our intui- 
tive perception of hazard by the intensity of its impacts: for example, Mercalli seismic intensity scale and the Palermo Technical Impact Hazard Scaleused by astronomers to rate the potential hazard of clash with a near-earth object (asteroid). Indeed, Eq. (4) is a specific manifestation of Weber Fechner basis psychophysics law (1860): $S=a \ln I+b$, the relationship between stimulus and perception is logarithmic. These examples are used here to justify the logarithmic relationship between the population hazard index and the perceived gravity of this hazard for the population.

Table 2 tells that several «urban okrugs» (districts) top the list of $H_{\text {pop }}$ values, with the respective scores between 4 and 6 . These are the towns of Naryan-Mar, Syktyvkar, Yakutsk and Lesosibirsk. The remaining districts have the scores between 1 and 3, of which 15 districts have score $=1 ; 30$ districts have score $=2$;

Table 2

Ranking of municipal districts by relative hazard of outbreaks of Siberian Anthrax among cattle (using territorial hazard index) and people (using population hazard index)

\begin{tabular}{|c|c|c|c|c|c|c|}
\hline \multicolumn{4}{|c|}{ Hazard for cattle } & \multicolumn{3}{|c|}{ Hazard for people } \\
\hline Subject of RF & Municipal district & $H I_{\text {terr }}$ & score & Municipal district & $H I_{\text {pop }}$ & score \\
\hline Yak-Arctic & Srednekolymsky & 21,26 & \multirow{5}{*}{6} & Naryan-Mar u.o. & 6747,26 & 6 \\
\hline Yak-West & Mirninsky & 13,24 & & Syktyvkar u.o. & 436,80 & 5 \\
\hline Yak-West & Niurbinsky & 12,45 & & Yakutsk u.o. & 357,38 & \\
\hline NAO & Naryan-Mar u.o. & 12,32 & & Lesosibirsku.o. & 75,85 & 4 \\
\hline Taimyr & Dudinka u.o. & 11,36 & & Chusovskoyu.o. & 17,71 & \\
\hline Taimyr & Ust-Yeniseisky & 9,54 & \multirow{3}{*}{5} & Ukhtau.o. & 17,46 & \\
\hline Yak-East & Oimyakonsky & 9,13 & & Namsky & 14,75 & \\
\hline Chukotka & Chukotka AO & 9,08 & & Ust-Aldansky & 9,98 & \\
\hline Yak-Centre & Ust-Aldansky & 8,76 & \multirow{11}{*}{-4} & Sosnogorsky & 6,78 & \\
\hline Yak-Centre & Amginsky & 8,20 & & Mirninsky & 5,76 & \\
\hline Yak-West & Viluisky & 8,19 & & Niurbinsky & 5,69 & \\
\hline KHMAO & Khanty-Mansiisky & 8,07 & & Churapchinsky & 5,53 & \\
\hline Koryak & Koryak AO & 8,02 & & Khangalassky & 5,22 & \\
\hline Evenk & Evenk AO & 7,61 & & Amginsky & 4,66 & \\
\hline Yak-Centre & Gorny & 7,45 & & Minusinsky & 4,40 & 3 \\
\hline Magadan & Magadan Oblast & 7,16 & & Viluisky & 3,71 & \\
\hline \begin{tabular}{|l|} 
Yak-Centre \\
\end{tabular} & Namsky & 7,12 & & Khanty-Mansiisky & 3,51 & \\
\hline Yak-West & Verkhneviluisky & 6,82 & & Verkhneviluisky & 3,41 & \\
\hline Yak-Centre & Kobyaisky & 6,82 & & Kudymkarsky & 3,21 & \\
\hline Yak-Arctic & Oleneksky & 6,13 & \multirow{3}{*}{3} & Abansky & 3,06 & \\
\hline Yak-South & Olekminsky & 4,96 & & Syktyvdinsky & 2,69 & \\
\hline YANAO & Yamalsky & 4,54 & & Megino-Kangalassky & 2,31 & \\
\hline Yak-West & Suntarsky & 4,39 & \multirow{6}{*}{2} & Krasnoturansky & 2,20 & \\
\hline Yak-Center & Khangalassky & 3,94 & & Magadan Oblast & 2,17 & \\
\hline Yak-Center & Yakutsk u.o. & 3,83 & & Nadymsky & 2,05 & \\
\hline Yak-Center & Churapchinsky & 3,29 & & Gorny & 1,96 & 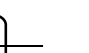 \\
\hline YANAO & Nadymsky & 3,17 & & \begin{tabular}{|l|} 
Sayansky \\
\end{tabular} & 1,95 & $\zeta 2$ \\
\hline Komi & Sosnogorsky & 2,64 & & Tattinsky & 1,82 & \\
\hline
\end{tabular}

$\mathrm{NAO}=$ Nenets Autonomous Oblast (Region);

YANAO $=$ Yamal-Nenets Autonomous Oblast;

$\mathrm{KHMAO}=$ Khanty-Mansi Autonomous Oblast;

$\mathrm{KPAO}=$ Komi-Permiatsky Autonomous Oblast;

Yakutia is subdivided into the five economic zones: Arctic, Centre, West, East, and South;

u.o. $=$ urban okrug (district). 
Table 2 (Continued)

\begin{tabular}{|c|c|c|c|c|c|c|}
\hline \multicolumn{4}{|c|}{ Hazard for cattle } & \multicolumn{3}{|c|}{ Hazard for people } \\
\hline Subject of RF & Municipal district & $H I_{\text {terr }}$ & score & Municipal district & $H I_{\text {pop }}$ & score \\
\hline Yak-Arctic & Zhigansky & 2,33 & & Priluzsky & 1,81 & \\
\hline Yak-Centre & Tattinsky & 2,12 & & Suntarsky & 1,79 & \\
\hline YANAO & Priuralsky & 2,07 & & Intau.o. & 1,67 & \\
\hline Yak-East & Tomponsky & 2,03 & & Pechora u.o. & 1,60 & \\
\hline Yak-East & Ust-Maisky & 1,97 & & Srednekolymsky & 1,27 & \\
\hline Komi & Intau.o. & 1,88 & & Kosinsly & 1,22 & \\
\hline Komi & Ukhtau.o. & 1,58 & & Dudinka u.o. & 1,15 & \\
\hline Krasnoyarsk & Abansky & 1,48 & & Gainsky & 1,08 & \\
\hline Krasnoyarsk & Sayansky & 1,48 & & Izhemsky & 0,91 & \\
\hline Komi & Priluzsky & 1,41 & & Elizovsky & 0,90 & \\
\hline KPAO & Gainsky & 1,37 & & Oimyakonsky & 0,84 & \\
\hline Yak-Arctic & Verkhoyansky & 1,34 & & Kobiaisky & 0,79 & \\
\hline Komi & Syktyvkarskyu.o. & 1,23 & & Olekminsky & 0,77 & $>2$ \\
\hline Yak-Arctic & Nizhnekolymsky & 1,17 & & Usinsku.o. & 0,66 & \\
\hline Komi & Izhemsky & 0,99 & & ChukotkaAO & 0,63 & \\
\hline Komi & Pechorau.o. & 0,95 & & Surgutsky & 0,56 & \\
\hline KPAO & Chusovskoyu.o. & 0,94 & & Irbeisky & 0,52 & \\
\hline Yak-Arctic & Verkhnekolymsky & 0,91 & & Yamalsky & 0,52 & \\
\hline Yak-Centre & Megino-Kangalassky & 0,88 & & Koryak AO & 0,51 & \\
\hline KHMAO & Kondinsky & 0,85 & & Kuraginsky & 0,51 & \\
\hline Komi & Syktyvdinsky & 0,82 & 1 & Idrinsky & 0,49 & \\
\hline Yak-Arctic & Bulunsky & 0,81 & 1 & Priuralsky & 0,48 & \\
\hline Yak-Arctic & Momsky & 0,78 & & Kondinsky & 0,48 & \\
\hline KPAO & Kosinsky & 0,68 & & Ust-Kulomsky & 0,47 & \\
\hline KPAO & Kudymkarsky & 0,68 & & Ust-Yeniseysky & 0,36 & \\
\hline Kamchatka & Elizovsky & 0,57 & & Kniazhpogostsky & 0,31 & \\
\hline Krasnoyarsk & Minusinsky & 0,55 & & Kolsky & 0,25 & \\
\hline Krasnoyarsk & Krasnoturansky & 0,55 & & Tomponsky & 0,19 & \\
\hline Komi & Ust-Kulomsky & 0,53 & & Evenk AO & 0,17 & \\
\hline KHMAO & Berezovsky & 0,50 & & Ust-Maisky & 0,15 & \\
\hline KHMAO & Surgutsky & 0,47 & & Berezovsky & 0,13 & \\
\hline Komi & Usinskyu.o. & 0,47 & & Verkhoyansky & 0,11 & \\
\hline Taimyr & Khatangsky & 0,45 & & Leshukonsky & 0,09 & \\
\hline Yak-Arctic & Eveno-Batyntaisky & 0,45 & & Mezensky & 0,08 & \\
\hline Komi & Knyazhpogostsky & 0,41 & & Oleneksky & 0,08 & \\
\hline Krasnoyarsk & Irbeisky & 0,37 & & Zhigansky & 0,07 & \\
\hline Krasnoyarsk & Lesosibirsku.o. & 0,32 & & Nizhnekolymsky & 0,06 & \\
\hline Arkhangelsk & Leshukonsky & 0,31 & & Verkhnekolymsky & 0,06 & \\
\hline Arkhangelsk & Mezensky & 0,31 & & Momsky & 0,03 & \\
\hline Krasnoyarsk & Idrinsky & 0,27 & & Bulunsky & 0,03 & \\
\hline Krasnoyarsk & Kuraginsky & 0,27 & & Eveno-Batyntaisky & 0,02 & \\
\hline Murmansk & Kolsky & 0,17 & & Khatangsky & 0,02 & \\
\hline
\end{tabular}

and 21 districts have score $=3$. The highest risks of Siberian anthrax outbreak among local people for the remaining districts were detected in Chusovskoy and Ukhta urban okrugs, Namsky and Ust-Aldansky uluses (districts) in Yakutia. Taking the value of $\mathrm{HI}_{\text {pop }}$ in NaryanMar $(6,747.26)$ as the maximum, the values of this index in these four administrative districts are above $1 \%$ (promille) of this maximum.
Therefore, the above mentioned eight urban districts should be considered as the priority ones when it comes to the risks of Siberian anthrax outbreaks among people. The urban districts (okrugs) with the highest $H I_{\text {pop }}$ might not actually have the catalogued cattle burials on their current territories, because the borders between the administrative districts shifted in many instances. For example, Naryan-Mar ur- 
ban okrug once included Posyolok Iskatelei village, which later was added to Zapolyarny district. Ukhta district existed within Komi Autonomus Soviet Socialist Republic between 1939 and 1963. Chusovskoy district existed within Perm region between 1964 and 2004, but the town of Chusovskoy was not part of this district.

The order of ranking by $\mathrm{HI}_{\text {terr }}$ values differs from the order of ranking by $H I_{p o p}$ values. For the decision makers, both indicators of the perceived hazard should be informative.

The priority districts could be chosen as the sites for field experiments to validate the mathematical models showing propagation of paleobiologic infections. Geometry stratification model is an example of such models; it identifies an area with maximum risk of noxious microorganisms reactivation from the cryptobiotic state due to permafrost degradation [29]. According to the authors of this research, Yamal Peninsula and Nort-East of Yakutia have the highest risks. The present research confirmed their conclusions with respect to Yakutia: Srendekolymsky district in the Arctic Zone of Yakutia; Mirninsky and Niurbinsky districts in West Yakutia have the highest $H I_{\text {terr }}$ values. The advantage of the hazard scoring method used in the present research is that it takes into account both the permafrost degradation rate and the documented numbers of cattle burial sites located in districts with perennial permafrost.

Conclusions. The adverse consequences of climate change in the Arctic create the need to develop various adaptation techniques. The recommendations for the prevention of natural focal infectious diseases should consider the available data on the territories with the most intense permafrost degradation. The field measurements taken by the geologists should provide necessary data on territories with the greatest deformations of perennial permafrost crust. Because the maximum rise in summer air temperatures is expected near the Arctic Coast of Central Siberia, this region should become the focus of interest for the paleobiologic monitoring over the current state of historic cattle burial sites where the diseased animals were buried at the 2-10 meters' depths. Infected carcasses of diseased reindeer could be frequently found scattered on the ground instead of being buried in specially designated and constructed 'burial sites'. Such unorganized burials are called «pestilence fields» and are marked so on veterinary maps. The publishing of the "Cadastre of Siberian anthrax burial sites» should be regularly updated and revised because there are more than 1 million wild reindeer and 1 million farm reindeer in the Arctic region. Intensive economic development of this region in the conditions of climate change may lead to Siberian anthrax outbreaks if the exact data on the historic cattle burial sites are absent. Natural disasters, climate change, permafrost degradation, earth excavations and other engineering and construction projects can activate the agents of infectious diseases near the earth's surface. The anomalously hot summer in 2016 might not be the single reason of the Siberian anthrax outbreak in Yamal Peninsula that year; other reasons were unjustified refusal to vaccinate reindeer and people and low public awareness [30]. The papers [26, 30] suggested several preventive measures to control potential Siberian anthrax outbreaks. Closest attention should be paid to each single case of this disease among deer. The risks of disease propagation from the soil foci should be carefully monitored. It is very important to regularly update and revisit the list of cattle burial sites, to inform the public about the existing health risks and disease prevention practices, and to continue to vaccinate deer. The authors also recommend further research to improve the dynamic geospatial models of Siberian anthrax propagation in the environment, taking into account the observed trends in global warming and permafrost degradation in the Russian Arctic.

Funding. for this research came from the grant program of Russian Foundation for Fundamental Research 18-05-60146 «Medical and Biological Factors of Social and Economic Development of Russian Arctic: Analysis and Predictions»».

Conflict of interests. the authors declare there is no any conflict of interests. 


\section{References}

1. Edel'geriev R.S.Kh., Romanovskaya A.A. New approaches to the adaptation to climate change: the case of the arctic zone of Russia. Meteorologiya i gidrologiya, 2020, no. 5, pp. 12-28 (in Russian).

2. Iglovskii S.A. Anthropogenic transformation of permafrost conditions of the European north of Russia and their consequences. Arktika i Sever, 2013, no. 10, pp. 107-1124 (in Russian).

3. Pörtner H.-O., Roberts D.C., Masson-Delmotte V., Zhai P., Tignor M., Poloczanska E., Mintenbeck K. [et al.]. IPCC Special Report on the Ocean and Cryosphere in a Changing Climate IPCC 2019 Summary for Policymakers. Summary for Policymakers, 2019, 36 p.

4. Climate Change and Land: An IPCC Special Report on Climate Change, Desertification, Land Degradation, Sustainable Land Management, Food Security, and Greenhouse Gas Fluxes in Terrestrial Ecosystems. IPCC, 2019. Available at: https://www.ipcc.ch/srccl/ (12.09.2020).

5. Revich B.A., Shaposnikov D.A., Shkolnik I.M. Projections of temperature-dependent mortality in Russian subarctic under climate change scenarios: a longitudinal study across several climate zones. IOP Conf. Ser.: Earth Environ. Sci, 2020, vol. 606, no. 012050, pp. 10. DOI: 10.1088/1755-1315/606/1/012050

6. Vasil'ev A.A., Gravis A.G., Gubar'kov A.A., Drozdov D.S., Korostelev Yu.V., Malkova G.V., Oblogov G.E. [et al.]. Permafrost degradation: results of the long-term geocryological monitoring in the western sector of Russian Arctic. Kriosfera Zemli, 2020, vol. 24, no. 2, pp. 15-30. DOI: 10.21782/KZ15607496-2020-2(15-30)

7. Nelson F.E., Anisimov O.F., Shiklomanov N.L. Subsidence risk from thawing permafrost. Nature, 2001, vol. 19, no. 410, pp. 889-890. DOI: 10.1038/35073746

8. Mokhov I.I., Eliseev A.V. Modelirovanie global'nykh klimaticheskikh izmenenii v XX-XXIII vekakh pri stsenariyakh antropogennykh vozdeistvii RCP [Modeling global climatic changes in the $20^{\text {th }}-21^{\text {st }}$ centuries under RCP anthropogenic impacts]. Doklady Akademii nauk, 2012, no. 6, pp. 732-736 (in Russian).

9. Pavlov A.V., Malkova G.V. Small-scale mapping of trends of the contemporary ground temperature changes in the Russian north. Kriosfera Zemli, 2009, vol. 13, no. 4, pp. 32-39 (in Russian).

10. Vorobyova E., Soina V., Gorlenko M., Minkovskaya N., Zalinova N., Mamukelashvili A., Gilichinsky D., Rivkina E., Vishnivetskaya T. The deep cold biosphere: facts and hypothesis. FEMS Microbiol. Rev., 1997, no. 20, pp. 277-290. DOI: 10.1111/j.1574-6976.1997.tb00314.x

11. Rivkina E., Shcherbakova V., Laurinavichuis K., Petrovskaya L., Krivushin K., Kraev G., Pecheritsina S., Gilichinsky D. Biogeochemistry of methane and methanogenic archaea in permafrost. FEMS Microbiol. Ecol., 2007, vol. 61, no. 1, pp. 1-15. DOI: 10.1111/j.1574-6941.2007.00315.x

12. Kochkina G.A., Ivanushkina N.E., Karasev S.G., Gurina L.V., Evtushenko D.I., Ozerskaya S.M., Gavrish E.Yu., Spirina E.V., Gilichinskii D.A., Vorob'eva E.A. Survival of micromycetes and actinobacteria under conditions of long-term natural cryopreservation. Mikrobiologiya, 2001, vol. 70, no. 3, pp. 412-420 (in Russian).

13. Shatilovich A.V., Shmakova S.V., Gubin D.A., Gilichinskii L.A. Viable protists in arctic permafrost. Kriosfera Zemli, 2010, vol. 14, no. 2, pp. 69-78 (in Russian).

14. Mills J.N., Gage K.L., Khan A.S. Potential influence of climate change on vector-born and zoonotic diseases: a review and proposed research plan. Environ. Health Perspect., 2010, vol. 118, no. 11, pp. 1507-1514. DOI: 10.1289/ehp.0901389

15. Semenza J.C., Suk J.E., Estevez V., Ebi K.L., Lingren E. Mapping climate change vulnerabilities to infection diseases in Europe. Environ. Health Perspect, 2012, vol. 120, no. 3, pp. 385-392. DOI: 10.1289/ehp.1103805

16. Laishev K.A., Zabrodin V.A. Problemy veterinarnogo blagopoluchiya po infektsionnym boleznyam v Severnom olenevodstve [Issues related to veterinary well-being as per communicable diseases in the Northern deer-raising]. Farm. Animals., 2012, vol. 1, no. 1, pp. 36-40 (in Russian).

17. Pavlova S.N., Barakhova L.D. Riski vozniknoveniya chrezvychainykh situatsii na territorii Respubliki Sakha (Yakutiya) [Risks of emergencies in Yakutia]. Natsional'nye interesy: prioritety $i$ bezopasnost', 2013, vol. 9, no. 47 (236), pp. 44-52 (in Russian).

18. Galkin V.V., Loktionova M.N., Simonova E.G., Khadartsev O.S. Problems in the safety of anthrax cattle burial grounds. Epidemiologiya i infektsionnye bolezni, 2007, no. 6, pp. 55-57 (in Russian).

19. Gavrilov V.A. Perspektivy resheniya problem biologicheskoi opasnosti sibireyazvennykh skotomogil'nikov [Prospects for solving the issue related to biological hazards occurring due to anthrax cattle burials]. Dezinfektsiya. Antiseptika, 2010, vol. 1, no. 3, pp. 12-15 (in Russian). 
20. Gavrilov V.A., Gryazneva T.N., Seliverstov V.V. Soil hearth anthrax: realities and challenges. Veterinariya, zootekhniya i biotekhnologiya, 2017, no. 8, pp. 17-22 (in Russian).

21. Dyagilev G.T., Neustroev M.P. Epidemiological and epizootological situation on anthrax in the republic of Sakha (Yakutia). Veterinariya i kormlenie, 2019, no. 7, pp. 11-13 (in Russian).

22. Karataeva T.D., Vasil'eva A.A. Epizooticheskaya obstanovka po sibirskoi yazve i ee profilaktike v Respublike Sakha (Yakutiya) [Epizootic situation as per anthrax and its prevention in Yakutia]. Vestnik veterinarii, 2007, no. 40-41, pp. 106-112 (in Russian).

23. Dyagilev G.T., Chernyavskii V.F., Egorov I.Ya., Sofronova O.N., Nikiforov O.I. Epizootological and epidemiological monitoring of anthrax in the arctic and eastern zones of Yakutia. Prirodnye resursy Arktiki i Subarktiki, 2019, vol. 24, no. 2, pp. 95-105 (in Russian).

24. Revich B., Podolnaya M. Thawing of permafrost may disturb historic cattle burial grounds in East Siberia. Global Health Action, 2011, no. 4, pp. 8482. DOI: 10.3402/gha.v4i0.8482

25. Letom 2016 g. na fone krupnoi i prodolzhitel'noi temperaturnoi anomalii v Yamalo-Nenetskom avtonomnom okruge nablyudaetsya vspyshka zabolevaemosti olenei sibirskoi yazvoi. Press-reliz 6 avgusta 2016 [In summer 2016 a large and long-term temperature anomaly resulted in anthrax outbreak among deer in the Yamal-Nenets Autonomous Area. Press release issued on August 6, 2016]. Institut global'nogo klimata i ekologii imeni akademika Yu.A. Izraelya, 2016. Available at: http://old.igce.ru/page/news_06082016 (12.09.2020) (in Russian).

26. Opyt likvidatsii vspyshki sibirskoi yazvy na Yamale v 2016 godu [Experience gained in anthrax outbreak elimination on the Yamal peninsula in 2016]. In: A.Yu. Popova, A.N. Kulichenko eds. Izhevsk, OOO «Print-2» Publ., 2017, 313 p. (in Russian).

27. Terebova S.V. The monitoring of anthrax outbreaks. Agrarnyi vestnik Primor'ya, 2017, no. 4 (8), pp. $42-47$ (in Russian).

28. Susloparov G.A., Kuzin A.A., Lantsov E.V. Medical-geographic characteristics natural and social conditions of development of epidemic process in the Yamal-Nenets autonomous district. Vestnik Rossiiskoi voenno-meditsinskoi akademii, 2018, no. S1, pp. 196-199 (in Russian).

29. Perevertin K.A., Vasil'ev T.A. Ekstsessy riskov paleobiozagryazneniya landshaftov v usloviyakh global'nogo potepleniya [Elevated risks of paleobiological contamination caused by global warming]. Materialy Shestoi konferentsii «Matematicheskoe modelirovanie v ekologii «EkoMatMod-2019», 2019, pp. 158-160 (in Russian).

30. Simonova E.G., Kartavaya S.F., Titkov A.V., Loktionova M.N., Raichich S.R., Tolpin V.A., Lupyan E.A., Platonov A.E. Anthrax in the territory of Yamal: assessment of epizootiological and epidemiological risks. Problemy osobo opasnykh infektsii, 2017, no. 1, pp. $89-93$ (in Russian).

Revich B.A., Shaposhnikov D.A., Raichich S.R., Saburova S.A., Simonova E.G. Creating zones in administrative districts located in the russian arctic region specific as per threats of cattle burials decay due to permafrost degradation. Health Risk Analysis, 2021, no. 1, pp. 115-125. DOI: 10.21668/health.risk/2021.1.12.eng

Received: 05.11.2020

Accepted: 03.03.2021

Published: 30.03 .2021 